\title{
The strong ground motion observation for the Wenchuan aftershock*
}

\author{
Ruizhi Wen ${ }^{1, \star}$ Zhenghua Zhou ${ }^{1}$ Xiaojun Li $^{1} \quad$ Cheng Yang $^{1}$ Yuhuan Wang ${ }^{1}$ \\ Quan Liu $^{1}$ Xiaotao Yin ${ }^{1}$ Mindu Zhou $^{2}$ and Jianwen Cui ${ }^{3}$ \\ ${ }^{1}$ Institute of Engineering Mechanics, China Earthquake Administration, Harbin 150080, China \\ ${ }^{2}$ Earthquake Administration of Gansu Province, Lanzhou 730000, China \\ ${ }^{3}$ Earthquake Administration of Yunnan Province, Kunming 650224, China
}

\begin{abstract}
In this paper, the mobile strong ground motion observation for the destructive earthquake is introduced. Considering the characteristics and its spatial distributions of aftershock, 59 strong ground motion instruments were installed along the Longmenshan fault area, and more than 2000 records have been accumulated. It shows that it is necessary to perform the mobile strong ground motion observation after the destructive earthquake, and the precious collected data could be applied for further research.
\end{abstract}

Key words: Wenchuan earthquake; mobile observation; strong ground motion

CLC number: P315.73 Document code: A

Strong ground motion observation data could be used as quantitative input of seismic analysis for engineering structure to verify the theory and method obtained from the earthquake investigation, and will be helpful to obtain more knowledge from the future earthquake disaster and to push forward the development of earthquake engineering research. Of course, the fixed strong ground motion stations are currently the main approach to capture the earthquake events. Since the first fixed strong ground motion station was built and started to run in Chinese mainland in 1962, the fixed strong ground motion networks have been made great progress. During the Tenth Five-year Plan, China National Digital Strong Ground Motion Network have been built and started to run by the China Earthquake Administration since March 2008. Luckily, when the great Wenchuan earthquake occurred on May 12, 2008, 388 strong ground motion stations and one site array captured 3-channel acceleration records of the main shock (Li et al, 2008).

As we know, the site locations of the fixed stations

\footnotetext{
${ }^{*}$ Received 8 September 2008; accepted in revised form 4 January 2009; published 10 April 2009

•Corresponding author. e-mail: ruizhi@iem.net.cn
}

had been regularly selected based on the network design guideline. If an earthquake occurs, the density of local strong ground motion station is not high enough to cover the observation area, the mobile, portable or temporal strong ground motion observation, will be encouraged to react quickly. The mobile strong ground motion instruments should be installed at a short time in the meizoseismal area. On the one hand, this will improve the density of local strong ground motion network, and on the other hand, it could capture more aftershock records. So when the short-term and imminent prediction of a large earthquake has been released or an earthquake has occurred, the emergency response of the mobile strong ground motion observation is required, which will be essential for capturing the main shock or the aftershock records.

The mobile strong ground motion observation was firstly practiced in China and has been proven that it is an effective way to capture the strong ground motion data. Its feature is immediacy and portability. The immediacy means when an earthquake occurs, the mobile team should be on the site at the first time. The aftershocks usually attenuated after the main shock quickly, both in the events number and intensity. Thus if the mobile instruments could be installed in a short time, more 
data could be captured. The portability means the installation of accelerometer is flexible. Before an earthquake, all the mobile instruments are maintained and run well in the storage in the strong motion center, and could be taken to the earthquake site.

In China, the strong ground motion network could not cover all the seismic area right now, and the station density is still lower, so the mobile strong ground motion observation have been applied as the main method to collect the data in the last few decades. Furthermore, combined with the method of the short-term and imminent earthquake prediction, the mobile observation even captured some main shock records, such as in Songpan earthquake and Shidian earthquake. This method had contributed most earthquake records of China mainland in history (Gao et al, 2001).

After the occurrence of the Wenchuan earthquake, China Earthquake Administration (CEA) quickly made response in time and sent out the team for the aftershock observation, aimed to service for the data collection and the emergency recovery. As one of the key involver, the process of Wenchuan Aftershock observation is introduced.

\section{Mobile strong ground motion obser- vation for Wenchuan aftershock}

Epicenter of Wenchuan earthquake is in the Longmenshan fault belt, which is a frequently-occurring earthquake region in northwest China. The substance under the Tibetan plateau flows to East China gradually, and is damped by the Sichuan basin and forced Sichuan basin to move up. As the results, the Longmenshan fault is formed. During Wenchuan earthquake, this fault ruptured only one direction from southwest to northeast under the compressive stress, then the stress released rather slowly and propagated in compressive thrust fault. Therefore, the trend of epicenters of the aftershocks extended to the northeast direction.

Having analyzed the characteristics of Wenchuan main shock, totally, 59 sets of instruments were deployed to capture the aftershock records and all observation information and site locations are shown in Tables 1 and 2 and Figure 1. Here are some basic rules for the installation:

1) In the hanging wall area, the instruments were installed along the fault direction, that is, DujiangyanPengzhou-Shifang- Mianzhu-Mianyang-Jiangyou-Guangyuan.

2) In the footwall area, the instruments were installed along three direction-lines approached the fault, that is, Wenchuan-Lixian, Heishui-Maoxian and Wenxian-Qingchuan.

3) More instruments were installed as near as to the Longmenshan fault to obtain more near-field strong ground motion data.

4) In the installation process, China National Digital Strong Ground Motion Network stations were also considered to improve the local station density.

In the mean time, some observation arrays are constructed as far as possible to satisfy some special observation purposes (Xie and Yu, 1982). Three types of observation arrays are implemented, which are the ground motion attenuation array, the basin effect observation array and the structural response observation array. As an example, a ground motion attenuation array consists of five mobile stations near Baoshan Corporation of Longmenshan town, Xiaoyudong, Xinxing, Tongji and Danjingshan. One basin effect observation array is constructed by eight mobile stations deployed near Jiangyou city and the observed data can be applied to analyze the influences of the basin topography and the abnormal building damage zones. One structural seismic response observation array is constructed by three mobile stations, which are deployed in Communication building of Dujiangyan city. The instruments are installed in different floors to study the characteristic and failure mechanism of structure.

\section{Instruments installation}

The main steps of installing instruments are as follows:

1) Select the flat ground as the instrument foundation

Table 1 The instruments for Wenchuan aftershock observation

\begin{tabular}{clc}
\hline No. & & \multicolumn{1}{c}{ Institution } \\
\hline 1 & $\begin{array}{l}\text { Institute of Engineering Mechanics, China Earthquake Administration } \\
\text { (China Strong Motion Network Center) }\end{array}$ & 27 sets of Etna and 1 set of GDQJ \\
2 & Earthquake Administration of Sichuan province & 3 sets of Etna \\
3 & Earthquake Administration of Hubei province & 2 sets of K2 \\
4 & Earthquake Administration of Gansu province (Northwest Strong Motion Network Center) & 15 sets of Etna and 5 sets of K2 \\
5 & Earthquake Administration of Yunnan province (Southwest Strong Motion Network Center) & 4 sets of Etna and 2 sets of K2 \\
\hline
\end{tabular}


Table 2 Mobile stations in Wenchuan earthquake

\begin{tabular}{|c|c|c|c|c|c|c|c|c|}
\hline No. & Station name & $\begin{array}{c}\text { Instrument } \\
\text { type }\end{array}$ & $\begin{array}{l}\text { Altitude } \\
/ \mathrm{m}\end{array}$ & Long $/{ }^{\circ} \mathrm{E}$ & Lat $/{ }^{\circ} \mathrm{N}$ & $\begin{array}{c}\text { Site } \\
\text { condition }\end{array}$ & $\begin{array}{l}\text { Date Con- } \\
\text { structed } \\
\text { a-mo-d }\end{array}$ & Remarks \\
\hline 1 & Linjiaba gas station & Etna & 784 & 104.67 & 32.03 & Bedrock & $2008-5-21$ & \\
\hline 2 & Government building of Guixi town & Etna & 653 & 104.63 & 31.98 & Bedrock & $2008-5-21$ & \\
\hline 3 & Hexi gas station & Etna & 506 & 104.7 & 31.73 & Soil & $2008-5-15$ & \\
\hline 4 & Government building of Jiangyou city & Etna & 507 & 104.74 & 31.78 & Soil & $2008-5-15$ & \\
\hline 5 & Rangshui gas station & Etna & 511 & 104.68 & 31.78 & Bedrock & $2008-5-15$ & \\
\hline 6 & Jiuling gas station & Etna & 494 & 104.67 & 31.64 & Soil & $2008-5-15$ & $\begin{array}{l}\text { Due to warning of overflow of the } \\
\text { quake lake, the instrument was } \\
\text { transferred to Dakang gas station } \\
\text { on May } 23,2008\end{array}$ \\
\hline 7 & Danjingshan toll station & Etna & 805 & 103.84 & 31.09 & Bedrock & $2008-5-16$ & \\
\hline 8 & Hanwang gas station & Etna & 667 & 104.17 & 31.43 & Soil & $2008-5-16$ & \\
\hline 9 & Yong'an gas station & Etna & 599 & 104.45 & 31.68 & Bedrock & $2008-5-16$ & \\
\hline 10 & Huagai gas station & Etna & 520 & 104.54 & 31.54 & Soil & $2008-5-16$ & $\begin{array}{l}\text { Following earthquake short-term } \\
\text { prediction, the instrument was } \\
\text { transferred to Huangtu town in } \\
\text { Anxian on May } 31,2008\end{array}$ \\
\hline 11 & CEA emergency response office in Puyang town & K2 & 676 & 103.67 & 31.03 & Soil & $2008-5-18$ & \\
\hline 12 & Government building of Yutang town & K2 & 710 & 103.61 & 30.96 & Bedrock & $2008-5-18$ & $\begin{array}{l}\text { Following earthquake short-term } \\
\text { prediction, the instrument was } \\
\text { transferred to Baoshan corporation } \\
\text { of Longmenshan town on May 30, } \\
2008\end{array}$ \\
\hline 13 & Xiaoyudong town & Etna & 983 & 103.75 & 31.18 & Bedrock & $2008-5-20$ & \\
\hline 14 & Tongji town & Etna & 848 & 103.83 & 31.16 & Bedrock & $2008-5-20$ & \\
\hline 15 & Xinxing town & GDQJ & 791 & 103.85 & 31.12 & Bedrock & $2008-5-20$ & \\
\hline 16 & Gymnasium of Dujiangyan city & Etna & 670 & 103.64 & 30.97 & Soil & $2008-5-14$ & $\begin{array}{l}\text { Due to retreating of CEA emer- } \\
\text { gency response office, the instru- } \\
\text { ment was transferred to Earthquake } \\
\text { Administration of Dujiangyan on } \\
\text { June } 4,2008\end{array}$ \\
\hline 17 & Chongyi toll station & Etna & 655 & 103.72 & 30.91 & Soil & $2008-5-14$ & $\begin{array}{l}\text { Following earthquake short-term } \\
\text { prediction, the instrument was } \\
\text { transferred to Linjiaba gas station } \\
\text { on May } 21,2008\end{array}$ \\
\hline 18 & Juyuan toll station & Etna & 669 & 103.68 & 30.95 & Soil & $2008-5-14$ & $\begin{array}{l}\text { Following earthquake short-term pre- } \\
\text { diction, the instrument was transferred } \\
\text { to government building of Tongji town } \\
\text { on May } 20,2008\end{array}$ \\
\hline 19 & Dakang gas station & Etna & 599 & 104.73 & 31.85 & Bedrock & $2008-05-23$ & \\
\hline 20 & Government building of Dayuan town & Etna & 753 & 105.24 & 32.42 & Bedrock & $2008-05-30$ & \\
\hline 21 & Power station of Caixi village in Malu town & Etna & 600 & 105.28 & 32.27 & Bedrock & 2008-05-30 & \\
\hline 22 & Jinshan village of Jinshanzi town & Etna & 622 & 105.32 & 32.18 & Bedrock & 2008-05-30 & \\
\hline 23 & Baoshan corporation of Longmenshan town & Etna & & 103.78 & 31.24 & Bedrock & 2008-05-30 & \\
\hline 24 & Huangtu town & Etna & 526 & 104.46 & 31.58 & Soil & $2008-05-31$ & \\
\hline 25 & Government building of Hongyan town & Etna & 587 & 104 & 31.14 & Soil & $2008-05-16$ & $\begin{array}{l}\text { Following earthquake short-term } \\
\text { prediction, the instrument was trans- } \\
\text { ferred to government building of } \\
\text { Xiaoyudong town on May 20, } 2008\end{array}$ \\
\hline 26 & Pengzhou city & Etna & 572 & 103.94 & 30.96 & Soil & 2008-05-16 & $\begin{array}{l}\text { Considering aftershock tendency, the } \\
\text { instrument was transferred to gov- } \\
\text { ernment building of Guixi town on } \\
\text { May 20, } 2008\end{array}$ \\
\hline 27 & Communication Building of Dujiangyan city & Etna & 670 & 103.65 & 30.97 & $\begin{array}{l}\text { Struc- } \\
\text { ture }\end{array}$ & $2008-05-28$ & $\begin{array}{l}\text { Structural seismic response observa- } \\
\text { tion array, including } 3 \text { instruments in } \\
\text { the first floor, forth floor and top } \\
\text { floor }\end{array}$ \\
\hline 28 & Zhongmiao town & Etna & 578 & 105.35 & 32.77 & Soil & $2008-05-23$ & \\
\hline 29 & Hillside of Wenxian station & Etna & 960 & 104.67 & 32.94 & Bedrock & $2008-05-17$ & \\
\hline 30 & Hill cave of Wenxian station & Etna & 940 & 104.67 & 32.94 & Bedrock & 2008-05-17 & \\
\hline 31 & Shifang & Etna & 972 & 104.56 & 33 & Bedrock & $2008-05-23$ & \\
\hline 32 & Danbao & Etna & 860 & 104.76 & 32.86 & Bedrock & $2008-05-24$ & \\
\hline 33 & Bikou & Etna & 579 & 105.24 & 32.75 & Bedrock & $2008-05-23$ & \\
\hline
\end{tabular}


Continuation of Table 2

\begin{tabular}{|c|c|c|c|c|c|c|c|c|}
\hline No. & Station name & $\begin{array}{l}\text { Instrument } \\
\text { type }\end{array}$ & $\begin{array}{l}\text { Altitude } \\
/ \mathrm{m}\end{array}$ & Long $/{ }^{\circ} \mathrm{E}$ & Lat $/{ }^{\circ} \mathrm{N}$ & $\begin{array}{c}\text { Site } \\
\text { condition }\end{array}$ & $\begin{array}{c}\text { Date Constructed } \\
\text { a-mo-d }\end{array}$ & Remarks \\
\hline 34 & Hillfoot of Wenxian station & Etna & 927 & 104.67 & 32.94 & Bedrock & $2008-05-17$ & \\
\hline 35 & Shijiba & Etna & 1091 & 104.44 & 33.06 & Bedrock & $2008-05-23$ & \\
\hline 36 & Hill top of Wenxian station & Etna & 969 & 104.67 & 32.94 & Bedrock & $2008-05-17$ & \\
\hline 37 & Yulei & Etna & 702 & 105.02 & 32.83 & Bedrock & $2008-05-24$ & \\
\hline 38 & Shazhou town & Etna & 562 & 105.47 & 32.67 & Bedrock & $2008-05-28$ & \\
\hline 39 & Yaodu & Etna & 569 & 105.43 & 32.77 & Bedrock & $2008-05-28$ & \\
\hline 41 & Waina & Etna & 846 & 105.05 & 33.2 & Bedrock & $2008-05-21$ & \\
\hline 42 & Qiaotou & $\mathrm{K} 2$ & 1008 & 104.8 & 33.11 & Bedrock & $2008-05-21$ & \\
\hline 43 & Lixian Country town & $\mathrm{K} 2$ & 1081 & 103.16 & 31.45 & Soil & 2008-05-14 & \\
\hline 44 & Government building of Tonghua town & $\mathrm{K} 2$ & 1209 & 103.42 & 31.56 & Bedrock & 2008-05-14 & \\
\hline 45 & Government building of Mianchi town & $\mathrm{K} 2$ & 1165 & 103.5 & 31.36 & Bedrock & $2008-05-18$ & \\
\hline 47 & Fuli gas station & Etna & 1110 & 103.61 & 31.49 & Bedrock & $2008-05-24$ & \\
\hline 48 & Xiaolong primary school of Nanping town & Etna & 297 & 106.15 & 30.84 & Bedrock & $2008-05-26$ & \\
\hline 49 & Huilong hydrologic station of Maoxian & Etna & 1672 & 103.66 & 31.83 & Bedrock & 2008-06-03 & \\
\hline 50 & Government building of Shidaguan town of Maoxian & Etna & 1724 & 103.68 & 31.9 & Bedrock & 2008-06-03 & \\
\hline 51 & Seergu gas station & Etna & 1811 & 103.41 & 31.94 & Bedrock & 2008-06-03 & \\
\hline 52 & Huigui restaurant of Huilong town of Maoxian & $\mathrm{K} 2$ & 1666 & 103.78 & 31.84 & Bedrock & $2008-06-03$ & \\
\hline 53 & Government building of Feihong town of Maoxian & Etna & 1643 & 103.73 & 31.79 & Bedrock & 2008-06-03 & \\
\hline 54 & Hospital of Goukou town & $\mathrm{K} 2$ & 1614 & 103.77 & 31.77 & Bedrock & 2008-06-03 & \\
\hline 55 & Seismological Bureau of Dujiangyan city & Etna & 682 & 103.61 & 31 & Soil & 2008-06-04 & \\
\hline 56 & Douchui Hill-1 & Etna & 1058 & 104.8 & 31.9 & Soil & $2008-06-25$ & Terrain effect array, in the hill top \\
\hline 57 & Douchui Hill-2 & Etna & 995 & 104.67 & 31.91 & Soil & $2008-06-25$ & Terrain effect array, in the hill foot \\
\hline 58 & Group 6 of Nanta village of Jiangyou city & Etna & 549 & 104.78 & 31.84 & Soil & $2008-06-25$ & Basin effect array \\
\hline 59 & Group 3 of Dahe village of Jiangyou city & Etna & 552 & 104.78 & 31.85 & Soil & $2008-06-25$ & Basin effect array \\
\hline 60 & Group 4 of Dahe village of Jiangyou city & Etna & 583 & 104.78 & 31.86 & Soil & $2008-06-25$ & Basin effect array \\
\hline 61 & The forth Panchang steelmaking plant of Jiangyou city & Etna & 613 & 104.77 & 31.89 & Soil & $2008-06-25$ & Basin effect array \\
\hline 62 & Taibai middle school of Jiangyou city & Etna & 616 & 104.77 & 31.88 & Soil & $2008-06-25$ & Basin effect array \\
\hline 63 & Group 3 of Xiping village of Jiangyou city & Etna & 553 & 104.78 & 31.87 & Soil & $2008-06-25$ & Basin effect array \\
\hline
\end{tabular}

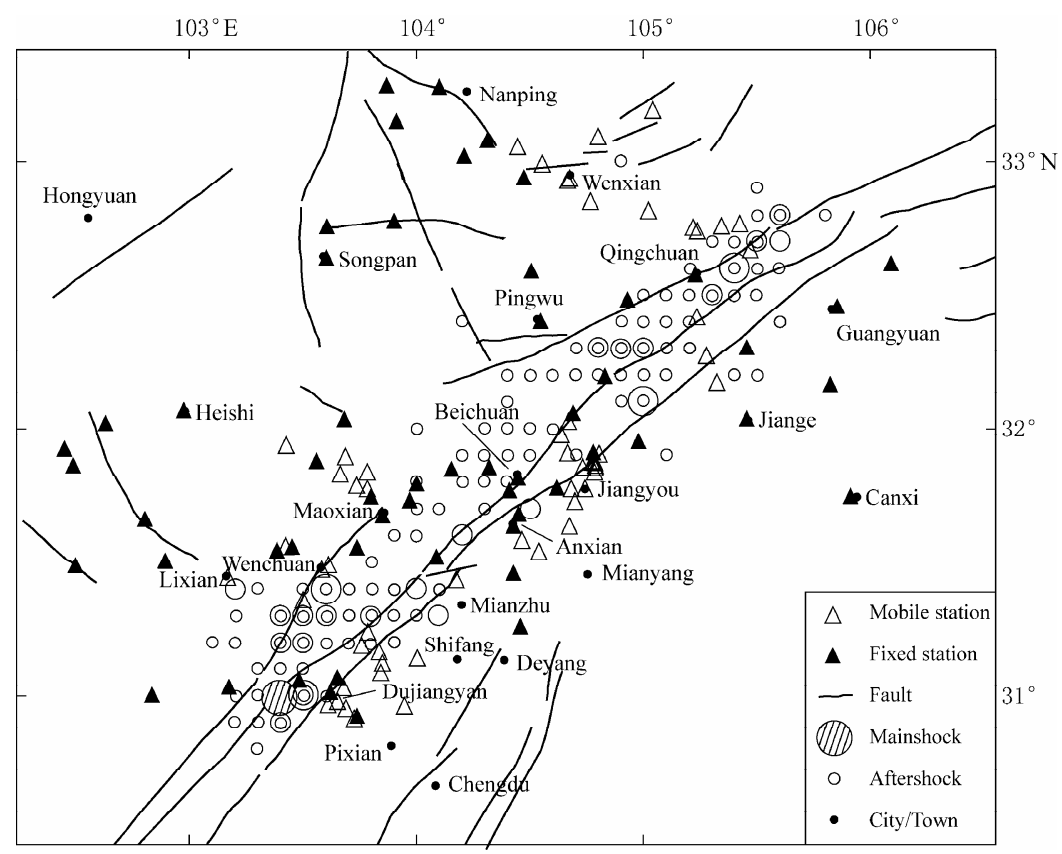

Figure 1 Distribution of mobile stations and China fixed station network for Wenchuan earthquake (Aftershock before June 23, 2008, $M \geq 4.0$ ). 
and make sure the surface even as far as possible.

2) Measure the south-north azimuth by the geological compass, then mark a cross on the surface of the foundation for the installation.

3) Check the south-north azimuth, and adjust the level bubble to make sure the accelerometer on a horizontal plane. Then glue the instruments on the ground or load some heavy stone on the top of the instrument box.

4) Adjust the zero point of the instrument and make sure the zero position less than $25 \mathrm{mV}$.

When installing the instruments, we comply with related technical standard and equipment specification strictly. Generally, the accelerometer is required to fasten on the

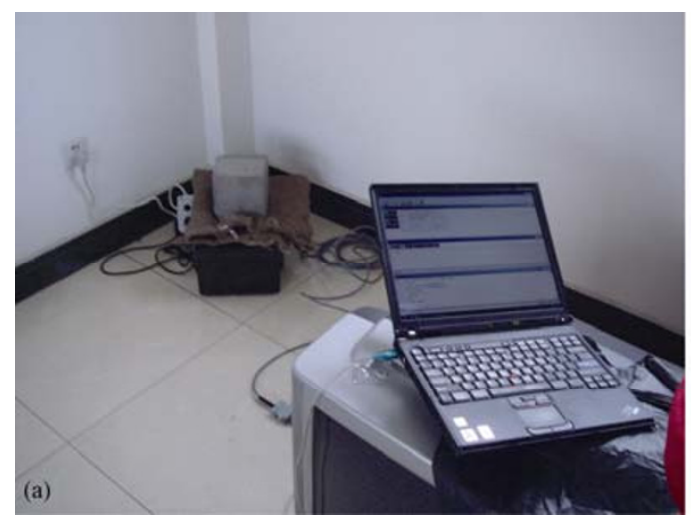

Figure 2 The comparison of mobile and fixed instrument installation.

\section{Typical records}

At 4:23 pm May 25, 2008, an aftershock broke out. Its magnitude was $M 6.4$ and epicenter was $105.4^{\circ} \mathrm{E}$ and $32.6^{\circ} \mathrm{N}$. More than 15 mobile stations have been triggered and recorded this event, and Figure 3 shows the station locations. In this paper, two typical time histories have been given, one is in the Linjiaba gas station, the epicentral distance is about $90 \mathrm{~km}$, and peak ground acceleration is about $122 \mathrm{Gal}$, as shown in Figure 4. Another is in the Hexi gas station, the epicentral distance is about $120 \mathrm{~km}$, and the peak ground acceleration is about $54 \mathrm{Gal}$, as shown in Figure 5. It should be noticed that the shortest epicentral distance is more than $90 \mathrm{~km}$. This is because our observation plan was to observe the aftershocks along fault strike from the main shock epicenter to north-east, and we did not have enough time to install all the mobile stations near M6.4 aftershock epicenter before it broke out.

Figure 6 shows the comparison of the observed and empirical values of PGA in this aftershock. The solid circles represent the PGA along the Major axis, while foundation firmly. Otherwise the instruments will slide along horizontal direction during the earthquake. Consequently, the earthquake records will have more distortion, maybe be useless. Figure 2 shows the comparison of mobile and fixed instruments installation. Due to the limitation of local site and work conditions after Wenchuan earthquake, the mobile instrument, Etna recorder with the inside accelerometer in Figure $2 \mathrm{a}$, is glued on the ground with some sacks on the top of housing, which the site condition for most of mobile station could be classified to soil station. For the typical fixed station in Figure 2b, the sensor is usually screwed on the special pillar foundation.

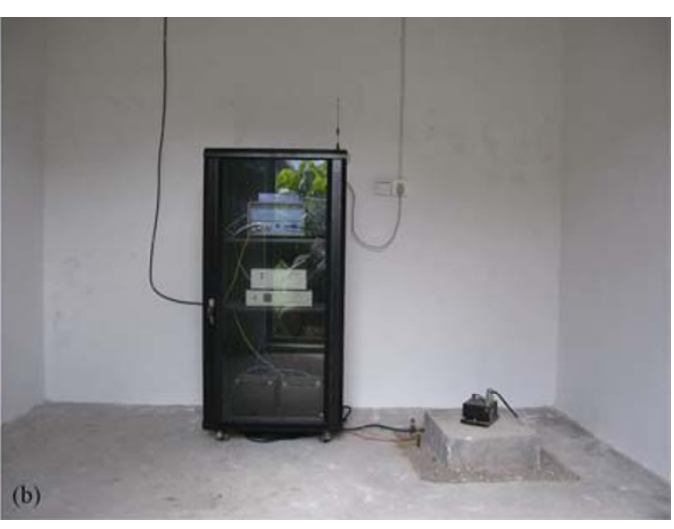

the open circles represent the PGA along the Minor axis. The empirical attenuation relationship was proposed by seismic ground motion parameter zonation map of China (State Bureau of Quality and Technical

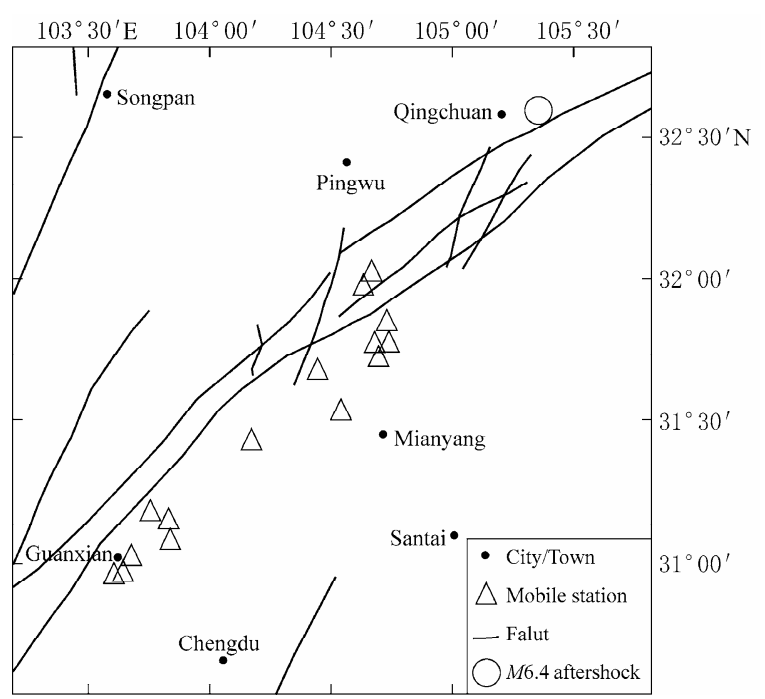

Figure 315 mobile stations recording $M_{\mathrm{S}} 6.4$ aftershock at May 25, 2008. 

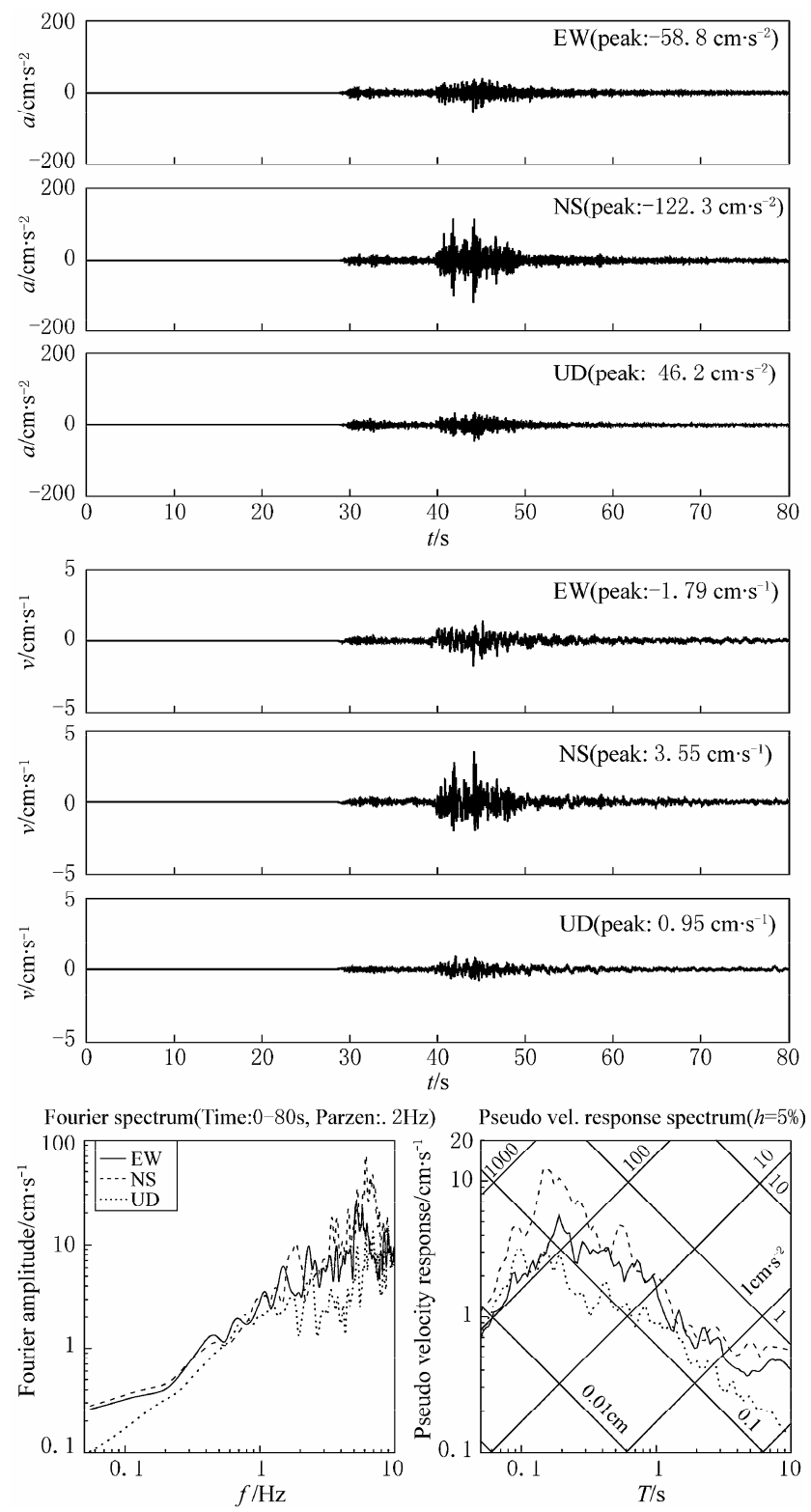

Figure 4 The strong motion data of Linjiaba gas station.

Supervision, 2001). It clearly shows that most of the observed data is above the curve and this maybe explained by the local site amplification.

\section{Conclusions}

The advanced digital strong ground motion instruments are adopted in the Wenchuan aftershock observation and this will mark a milestone in China strong motion observation. After three month consecutive running, more than 2000 groups of 3-channel seismic acceleration record are obtained and the maximum PGA is more than $800 \mathrm{Gal}$.

Having considered the ground motion attenuation,
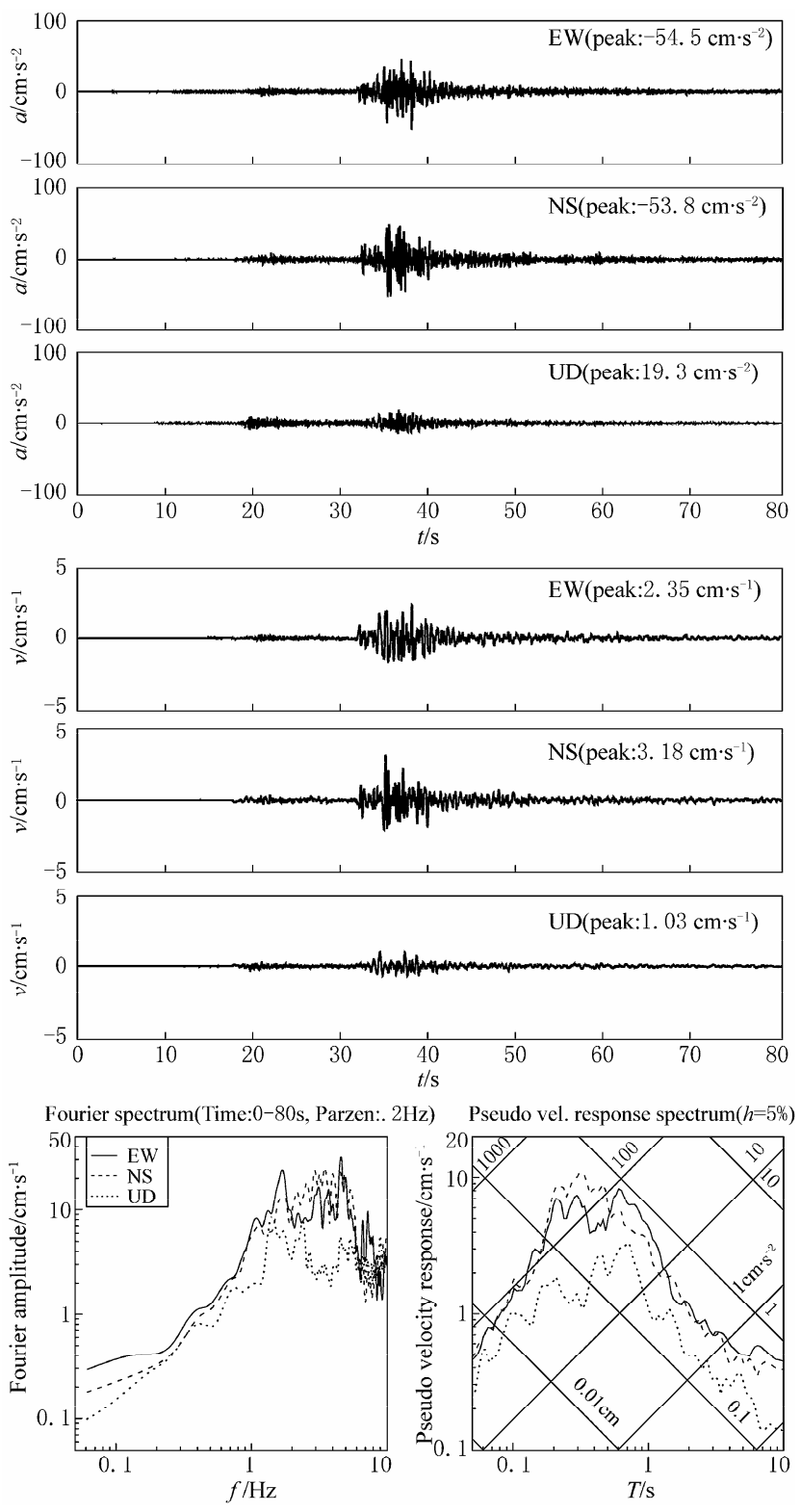

Figure 5 The strong motion data of Hexi gas station.

terrain and basin effect, and engineering structure response in this aftershock observation, three kinds of special arrays have accumulated lots of records, which will greatly contribute to further researches on obtaining statistical relationship of ground motion attenuation, analyzing basin terrain effect and engineering structure response.

In addition, some experiences about mobile strong ground motion observation are summarized from Wenchuan earthquake observation.

1) Due to the traffic interruption, it is until May 14 that the observation teams arrived at the earthquake field. Consequently, it lost 2 days of the observation for after- 


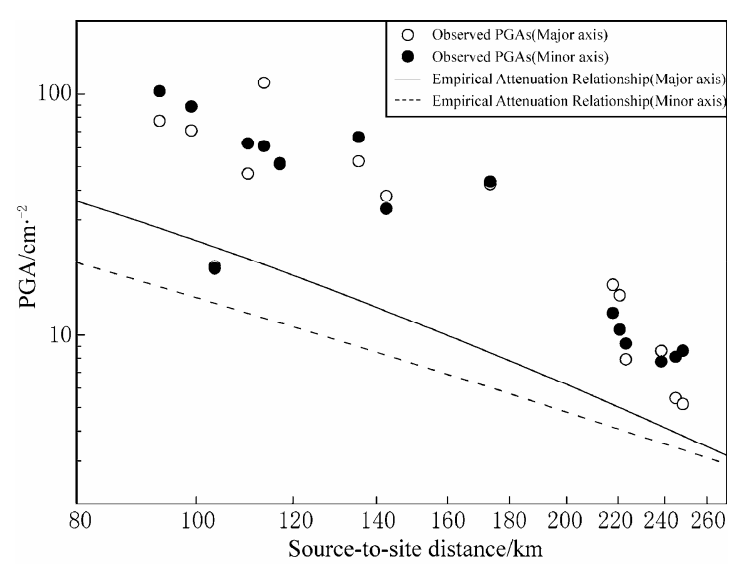

Figure 6 The observed PGAs of M6.4 aftershock and the empirical attenuation curve.

shock on May 12 and May 13. Thus, the guarantee mechanism of mobile earthquake observation procedure should be established as a regular rule so that the mobile observation team could act in first time and this will increase the chance of capturing large aftershock record.

2) The electric power facilities are destroyed after destructive earthquake. A prominent problem for the mobile observation is how to find steady electric power. Fortunately, there are some temporary power generating equipments in some government buildings and gas stations, and the observation instruments can be installed and run there. Thus, the power supply of mobile observation instruments must be improved so that they can give the power under the extreme field conditions, and the selection of the station location is free without any limitation.
3) It should be paid more attentions on the instrument installation technique of mobile earthquake observation. When selecting mobile station location, the earthquake characteristic, fault rupture direction and site condition should be considered to make sure that the limited instruments can play the maximum functionality in the limited time.

Acknowledgements This study is supported by MOST of China under Grant No. 2006BAC13B02, CEA under Grant No. 200808026 and IEM/CEA under Grant No. 0618001. We thank for the support of the Division of Defense and Prevention, CEA, the CEA office for Wenchuan Earthquake Emergency and Response. We also thank for the all colleagues from Earthquake Administration of Sichuan province, Earthquake Administration of Yunnan province, Earthquake Administration of Gansu rovince, Earthquake Administration of Hubei province. Thanks for the support and the understanding of the people in the meizoseismal area.

\section{References}

Gao G., Yu H and Li S (2001). Strong ground motion observation for China mainland. World Earthquake Engineering 17(4): 13-18 (in Chinese with English abstract).

Li X, Zhou Z, Yu H and Wen R (2008). Preliminary analysis of strong ground motion observation for Wenchuan $M_{\mathrm{S}} 8.0$ earthquake. In: Seminar of building damage analysis and reconstruction for Wenchuan earthquake. China Architecture\& Building Press Beijing, 28-29 (in Chinese).

Xie L and Yu S (1982). Strong Ground Motion Observation and Analysis Principle. Seismological Press, Beijing (in Chinese).

State Bureau of Quality and Technical Supervision (2001). Seismic Ground Motion Parameter Zonation Map of China (GB18306-2001). Standards Press of China, Beijing (in Chinese). 